\title{
Efficacy of tilmicosin for treatment of pasteurellosis in Holstein calves: A controlled clinical trial
}

\author{
Mohamed Bedeer $^{1 *}$, Mohamed El-Diasty ${ }^{2}$, Mohamed Elsayed ${ }^{1}$ \\ ${ }^{1}$ Department of Pharmacology, Faculty of Veterinary Medicine, Mansoura University, Egypt \\ ${ }^{2}$ Animal Health Research Institute (AHRI), Mansoura Provincial Lab, Egypt
}

\section{ARTICLE HISTORY}

Received: 24.06 .2020

Revised: 03.12.2020

Accepted: 23.12 .2020

Address correspondence to Mohamed Bedeer; Tel. , E-mail: vet_bedeer1010@yahoo.com

\section{ABSTRACT}

\begin{abstract}
Objective: To assess the effectiveness of Tilmicosin in the treatment of pasteurellosis in Holstein calves.

Design: Controlled study.

Animals: Twenty Holstein Calves

Procedures: 10 Holstein Calves suspected to be suffering from Bovine respiratory distress (BRD) were treated with Tilmicosin and another 10 Holstein healthy calves under the same conditions of hygiene, nutrition, and management were used as a control group. The nasal swap was collected from the two groups for bacteriological isolation and blood samples were collected for hematological and biochemical analysis at zero, $7^{\text {th }}, 14^{\text {th }}$ days.

Results: Bacteriological isolation revealed that Pasteurella multocida and Mannheimia haemolytica serotype A were the most causative agents of pasteurellosis in the infected calves. The hematological analysis of the tilmicosin treated group showed a significant decrease $(P<0.05)$ in RBCs at zero week and the second week, with a significant increase $(P<0.05)$ in WBCs at the second week, with no significant change $(P>0.05)$ in hemoglobin, but there is a significant decrease in hematocrit at Zero Week and second week, and a significant decrease $(P<0.05)$ of MCV at zero week and first week, with a significant increase of $\mathrm{MCH}$ at zero weeks, with a significant increase in $\mathrm{MCHC}$ at zero weeks and the second week with a significant increase in Plt at second week, a significant decrease in lymphocyte at zero week and second week but there is a significant increase of neutrophil at zero weeks and the second week with a significant decrease at the first week. The biochemical analysis showed no significant change in total protein and albumin with a significant increase in GOT at the first week, a significant decrease in GPT at second week, a significant increase in ALP at Zero weeks, and first week there is a significant increase in Gb at zero weeks, first week and second week, albumin concentration was significantly decreased, a significant decrease of creatinine at zero weeks and a significant increase in the first week.

Conclusion and clinical relevance: In conclusion, tilmicosin induced a significant decrease in RBCs \& lymphocyte and a significant increase in WBCs, neutrophil, platelets, and globulin.
\end{abstract}

Keywords: Tilmicosin; Pasterullosis; Calves

\section{INTRODUCTION}

Bovine respiratory disease (BRD) is a general term for respiratory disease in cattle and the most ubiquitous disease all over the world. Bovine respiratory disease is also one of the most major causes of morbidity and mortality with severe economic losses in the cattle industry due to loss of production, labor, increased time on feed, prophylaxis, and metaphylaxis treatments [1], [2].

They are often referred to as BRD is responsible for subvert the cow-calf business and the disease result from dramatic interaction between the stress condition (environmental conditions and herd management), causative agent (virus agents and bacterial agents), and animal immunity. These agents often produce mild clinical to severe clinical signs and death within 24 to 36 hours or may cause permanent lung damage as fibrosis, adhesions, and/or abscesses, in chronic cases, which will impact performance. That is why early recognition and treatment of BRDC are so important [3], [4] \& [5]. However, the affected calves exhibiting signs of fever, depression, off food, separate themselves from the rest of the pen, abnormal nasal discharge, cough, and abnormal lung sound [6-7].

Pasteurella is a major cause of severe "shipping fever" pneumonia when combined with stress and with and without viral agents. The major bacterial pathogen involved in pneumonic pasteurellosis of cattle is Mannheimia haemolytica serotype 1 [8].

Macrolides are active against important animal pathogens and their spectrum in general covers Gram-positive bacteria 
and Gram-negative bacteria like Mannheimia haemolytica and Pasteurella multocida [9]. Macrolides also have significant immunomodulatory effects independent of their antimicrobial activity; for example, it has been shown to enhance the proinflammatory reaction of the host, to improve phagocytosis and to reduce local inflammation [10].

Tilmicosin is one from the macrolides group which used successfully as a prophylactic for infection in feedlot animals [11] and is also an effective therapy [12] for undifferentiated bovine respiratory disease. The most frequent bacterial pathogen encountered in these infections is Mannheimia haemolytica -A1 [13]. Young calves are also susceptible to infection with Mannheimia haemolytica as a secondary invader within the enzootic pneumonia complex [14].

The current study was conducted to evaluate the effectiveness of Tilmicosin for the treatment of Holstein calves suffering from clinical signs of BRD with special reference to some hematological and biochemical parameters.

\section{MATERIALS AND METHODS}

The experimental protocol was approved by the Faculty of Veterinary Medicine, Mansoura University, Egypt and Animal Health Research Institute Committee on Animal Care.

\subsection{Animals}

Our study was conducted in a Holstein dairy farm at Dakahlia Governorate suffered from a high incidence of BRD clinical signs especially in the calves (40:70 days age-old) with body weight ranged from 65 to $80 \mathrm{~kg}$. Calves that suspected to suffer from BRD were visually examined for the presence of nasal discharge, respiratory distress, cough, depression, and inappetence. After clinical signs observation, the rectal temperature of the calf was recorded using the clinical scoring system [15]. Ten diseased calves that suffered from BRD were chosen as a diseased group compared to another healthy ten calves has served as a control group. All tested animals were kept under the same conditions of hygiene, nutrition, and management. Clinical examination for all calves was done according to Radostits et al., [16].

\subsection{Treatment}

First diseased group injected by Tilmicosin ( Pneumotac ${ }^{\circledR}$ : each $\mathrm{ml}$ contain Tilmicosin phosphate $333.828 \mathrm{mg}$ equivalent to Tilmicosin base $300 \mathrm{mg}$, manufactured by ADWIA co. S.A.D. 10th Ramadan city, Egypt) in dose $1 \mathrm{ml} / 30 \mathrm{~kg}$ B.W. S/C [17], while the second group was kept as a control group.

\subsection{Samples}

Nasal swabs from clinically diseased calves were taken for bacteriologically isolation and identification as described by Kabeta et al. [8]. Blood samples were collected at 0, 7 and 14 days after treatment and used for hematology and biochemical analysis. Two blood samples were collected from each calf using a jugular vein puncture. The first blood sample was collected on a labeled test tube containing 5 mg k2EDTA in a concentration of $1 \mathrm{mg} / 1 \mathrm{ml}$ blood [2] as an anticoagulant for the determination of hematological parameters (RBCs count, $\mathrm{Hb}$ content, and PCV \%). The second blood sample was collected without anticoagulant, clotted at room temperature for $20 \mathrm{~min}$, centrifuged at $3000 \mathrm{rpm}$ for $10 \mathrm{~min}$, and then the clear nonhaemolyzed serum samples were separated and stored at $-20^{\circ} \mathrm{C}$ until subsequent biochemical analysis.

\subsection{Hematological and Biochemical analysis}

Total erythrocytic count (RBCs), hemoglobin concentration $(\mathrm{Hb})$, packed cell volume (PCV), Total leukocytic count (WBCs), and differential leukocytic counts were determined by a hematological analyzer as previously described by Jain, [18]. Serum total proteins (TP) were determined spectrophotometrically according to the method described Pagana and Pagana [19]. Albumin was determined calorimetrically using the dye-binding technique with bromocresol green and the $A / G$ ratio was calculated by dividing the albumin value over globulin value according to Fischbach and Dunning [20]. Serum globulin was determined by the differences between total protein and albumin according to Chernecky and Berger [21]. Serum samples were used also for the determination of aspartate transaminase (AST), alanine aminotransferase (ALT), creatine kinase (CK), and lactate dehydrogenase (LDH) using the special kits according to the method described by Pagana and Pagana [19], Thefeld [22] and Ghanem et al. [23] respectively. Serum urea and creatinine concentrations were also determined spectrophotometrically using special kits according to the method described by Walker et al., [24], Peake and Whiting [25], respectively.

\subsection{Bacteriological Isolation of $M$. haemolytica and $P$. multocida}

Bacteriological Isolation of $M$. haemolytica and $P$. multocida in the current study was performed according to Rimler and Rhoades, [26]. The Media and reagents for biochemical tests were prepared according to Jamaludin et al. [27] while, Serotyping of $P$. multocida isolates were analyzed using rapid slide agglutination test using capsular type $B$ antiserum according to Heddleston et al., [28] and Rimler and Rhoades, [26].

\subsection{Statistical analysis}

Statistical analysis was performed using IBM SPSS Statistics version 20 (IBM Armonk, NY, USA). The data were statistically analyzed using an independent sample $t$-test to compare healthy with the diseased animal as previously described by Graham et al., [29]. Values were represented as means \pm standard error (SE). All differences were considered statistically significant when $P<0.05$. 


\section{RESULTS}

\subsection{Clinical examination of calves under our experiment}

Clinical examination of animals under study showed a significant elevation $(P<0.05)$ of body temperature of diseased calves. Moreover, a significant decrease $(P<0.05)$ in ruminal movement rate was recorded in diseased animals compared to healthy calves. Nasal discharges with various degrees and ocular discharge were recorded in diseased animals compared to the control group. In details, two-calves showed mucoid discharge. While, mucopurulent and purulent discharges were observed in five and three- calves, respectively. Significant increases $(P<0.05)$ in respiratory and coughing rates were observed on diseased calves (Table 1$)$.

Table 1. Clinical findings calves with pasteurellosis.

\begin{tabular}{lll} 
Parameter & Control $(\mathrm{n}=10)$ & Diseased $(\mathrm{n}=10)$ \\
\hline Body Temp ${ }^{\circ} \mathrm{C}$ & $38.7 \pm 0.31^{\mathrm{b}}$ & $40.81 \pm 0.23^{\mathrm{a}}$ \\
Ruminal movement/minute & $3.54 \pm 0.21^{\mathrm{a}}$ & $1.87 \pm 0.14^{\mathrm{ba}}$ \\
Respiratory rate/minute & $35.86 \pm 2.18^{\mathrm{b}}$ & $60.54 \pm 3.54^{\mathrm{a}}$ \\
Coughing /minute & $0.12 \pm 0.01^{\mathrm{b}}$ & $8.65 \pm 0.23^{\mathrm{a}}$
\end{tabular}

Table 2. Biotyping of Pasteurella multocida and Mannheimia haemolytica isolates.

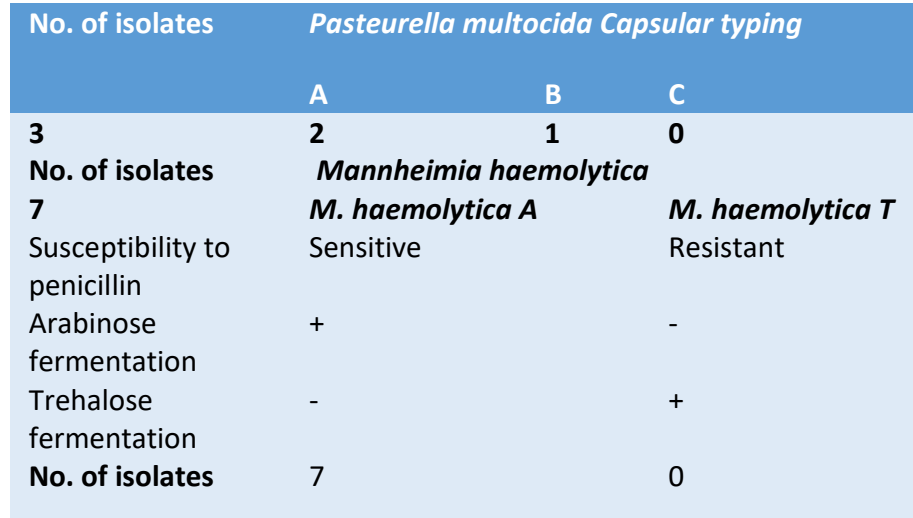

\subsection{Bacteriological isolation}

The obtained results showed that $30 \%$ of the nasal swap isolates from the infected calves was Pasteurella multocida and $70 \%$ was Mannheimia haemolytica serotype A.

\subsection{Clinical score for Cure rate}

Out of ten diseased animals, the animals exhibited loss depression, appetite loss, change in respiratory pattern, and fever were 3, 1, 4, and2, respectively. Depend on the Dart method the cure rate for the calves under experiment which treated with tilmicosin $10 \mathrm{mg} / \mathrm{kg}$. BW. by s/c was $7.5 \%$. After one weak of the experiment, one of the treated calves has died, post mortem examination was applied on the carcass, and samples from the lung were sent for histopathological examination.

\subsection{Hematological analysis}

The comparison between tilmicosin $10 \mathrm{mg} / \mathrm{kg}$.bwt .s/c injected calves group and control group show a significant decrease in RBCs count in zero weeks and the second week for the infected group, and that is confirmed by the hematocrit blood test (HCT) and red blood cells distribution width (RDWCV). The significant decrease in platelet count (PLT) in the second week for the tilmicosin-treated group with no significant change in mean platelet volume (MPV) and a significant decrease in platelet distribution width (PDW-CV) in zero weeks and the first week for tilmicosin treated group. (Table 3).

Table 3. Hematological parameters of control and Tilmicosintreated groups by $\mathrm{S} / \mathrm{C}$ injection in Holstein calves.

\begin{tabular}{|c|c|c|c|c|}
\hline parameter & group & Zero week & First week & $\begin{array}{l}\text { Second } \\
\text { week }\end{array}$ \\
\hline \multirow[t]{2}{*}{ RBCs $X 10^{6}$} & control & $3.95 \pm 0.46^{a}$ & $3.96 \pm 0.78^{a}$ & $4.87 \pm 0.41^{a}$ \\
\hline & Treated & $2.78 \pm 0.64^{b}$ & $4.46 \pm 0.88^{a}$ & $3.98 \pm 0.15^{b}$ \\
\hline \multirow[t]{2}{*}{ WBCs $\times 10^{3}$} & control & $5.65 \pm 0.14^{a}$ & $6.66 \pm 0.26^{a}$ & $6.18 \pm 0.63^{b}$ \\
\hline & Treated & $5.58 \pm 0.49^{a}$ & $5.85 \pm 0.35^{a}$ & $8.43 \pm 0.44^{a}$ \\
\hline \multirow[t]{2}{*}{$\mathrm{Hgb}(\mathrm{g} / \mathrm{L})$} & control & $6.70 \pm 0.53^{a}$ & $6.91 \pm 0.48^{a}$ & $6.73 \pm 0.57^{a}$ \\
\hline & Treated & $6.81 \pm 0.74^{a}$ & $6.86 \pm 0.59^{a}$ & $7.05 \pm 0.64^{a}$ \\
\hline \multirow[t]{2}{*}{ Hct (\%) } & control & $16.01 \pm 1.13^{a}$ & $14.81 \pm 2.95^{a}$ & $16.45 \pm 1.70^{\mathrm{a}}$ \\
\hline & Treated & $10.46 \pm 1.52^{b}$ & $14.11 \pm 2.69^{a}$ & $12.43 \pm 1.51^{b}$ \\
\hline \multirow[t]{2}{*}{$\mathrm{MCV}$} & control & $40.35 \pm 0.78^{a}$ & $38.16 \pm 4.88^{a}$ & $33.50 \pm 0.88^{\mathrm{a}}$ \\
\hline & Treated & $37.28 \pm 0.49^{b}$ & $33.00 \pm 1.71^{b}$ & $34.66 \pm 2.49^{a}$ \\
\hline \multirow[t]{2}{*}{$\mathrm{MCH}$} & control & $17.31 \pm 0.82^{\mathrm{b}}$ & $15.05 \pm 1.47^{a}$ & $13.86 \pm 0.29^{a}$ \\
\hline & Treated & $32.68 \pm 0.23^{a}$ & $15.16 \pm 1.42^{\mathrm{a}}$ & $13.88 \pm 0.23^{a}$ \\
\hline \multirow[t]{2}{*}{$\mathrm{MCHC}$} & control & $43.46 \pm 2.86^{b}$ & $40.56 \pm 1.53^{a}$ & $41.46 \pm 0.99^{b}$ \\
\hline & Treated & $90.58 \pm 2.72^{a}$ & $42.93 \pm 1.70^{a}$ & $44.03 \pm 0.20^{\mathrm{a}}$ \\
\hline \multirow[t]{2}{*}{ RDW-CV } & control & $16.18 \pm 0.78^{a}$ & $11.05 \pm 1.56^{a}$ & $15.20 \pm 0.51^{\mathrm{a}}$ \\
\hline & Treated & $13.70 \pm 0.29^{b}$ & $12.00 \pm 1.40^{\mathrm{a}}$ & $10.41 \pm 1.50^{b}$ \\
\hline \multirow[t]{2}{*}{ Plt X10 3} & control & $660.66 \pm 48.66^{a}$ & $\begin{array}{l}2349.16 \pm 953 \\
.15^{\mathrm{a}}\end{array}$ & $\begin{array}{l}1488.00 \pm 185 \\
.29^{b}\end{array}$ \\
\hline & Treated & $639.00 \pm 50.02^{a}$ & $\begin{array}{l}3110.33 \pm 811 \\
.76^{a}\end{array}$ & $\begin{array}{l}3938.33 \pm 105 \\
.19^{a}\end{array}$ \\
\hline \multirow[t]{2}{*}{ MPV } & control & $5.45 \pm 0.14^{\mathrm{a}}$ & $9.15 \pm 0.82^{\mathrm{a}}$ & $9.46 \pm 0.34^{a}$ \\
\hline & Treated & $5.80 \pm 0.24^{a}$ & $9.96 \pm 0.35^{a}$ & $10.61 \pm 0.32^{a}$ \\
\hline \multirow[t]{2}{*}{ Pct } & control & $0.35 \pm 0.03^{b}$ & $0.03 \pm 0.03^{a}$ & $0.29 \pm 0.01^{\mathrm{a}}$ \\
\hline & Treated & $2.73 \pm 2.49^{a}$ & $0.00 \pm 0.00^{a}$ & $0.00 \pm 0.00^{b}$ \\
\hline \multirow[t]{2}{*}{ PDW-CV } & control & $15.15 \pm 0.22^{\mathrm{a}}$ & $3.05 \pm 1.93^{a}$ & $2.98 \pm 0.18^{\mathrm{a}}$ \\
\hline & Treated & $7.82 \pm 0.43^{b}$ & $1.41 \pm 0.01^{b}$ & $2.93 \pm 0.15^{a}$ \\
\hline \multirow{2}{*}{$\begin{array}{l}\text { Lymphocyte } \\
\text { (\%) }\end{array}$} & control & $64.00 \pm 4.38^{\mathrm{a}}$ & $53.33 \pm 5.71^{\mathrm{a}}$ & $70.00 \pm 5.18^{a}$ \\
\hline & Treated & $52.33 \pm 3.17^{b}$ & $59.00 \pm 4.41^{a}$ & $49.66 \pm 2.49^{b}$ \\
\hline \multirow{2}{*}{$\begin{array}{l}\text { Monocyte } \\
(\%)\end{array}$} & control & $4.66 \pm 0.33^{a}$ & $4.00 \pm 0.36^{a}$ & $4.50 \pm 0.50^{a}$ \\
\hline & Treated & $4.16 \pm 0.54^{a}$ & $5.66 \pm 0.33^{a}$ & $5.16 \pm 0.74^{a}$ \\
\hline \multirow{2}{*}{$\begin{array}{l}\text { Neutrophil } \\
\text { (\%) }\end{array}$} & control & $21.33 \pm 2.30^{b}$ & $41.83 \pm 4.94^{\mathrm{a}}$ & $25.50 \pm 5.33^{b}$ \\
\hline & Treated & $41.83 \pm 2.45^{a}$ & $35.33 \pm 4.31^{b}$ & $45.16 \pm 2.49^{a}$ \\
\hline \multirow{2}{*}{$\begin{array}{l}\text { Eosinophil } \\
(\%)\end{array}$} & control & $0.00 \pm 0.00^{a}$ & $0.50 \pm 0.00^{a}$ & $0.00 \pm 0.00^{a}$ \\
\hline & Treated & $0.00 \pm 0.00^{a}$ & $0.00 \pm 0.00^{\mathrm{a}}$ & $0.00 \pm 0.00^{\mathrm{a}}$ \\
\hline
\end{tabular}

There is a significant increase in Procalcitonin (PCT) in zero weeks for the treated group with a significant decrease in the second week (Table 3), while there was a significant increase in WBCs in the second week for the tilmicosin treated.

\subsection{Biochemical analysis}


The changes in biochemical parameters for the tilmicosin $10 \mathrm{mg} / \mathrm{kg}$.bwt subcutanous injected calves showed a significant increase $(P<0.05)$ in globulin level with on significant change $(P>0.05)$ in TP and albumin level. However, the significant increase $(P<0.05)$ in alkaline phosphatase level in the zero week and the first week for the same group indicates injury in the liver, gall bladder, and bone marrow but there was a significant decrease $(P<0.05)$ of ALT liver enzyme in the second week ( Table 4).. AST liver enzyme showed a significant increase $(P<0.05)$ in the first week only (Table 4$)$. In the present study, the renal function is reflected by urea level which showed a significant increase $(P<0.05)$ in the first week (Table 4)

Table 4. Biochemical parameters of control and Tilmicosin (10 $\mathrm{mg} / \mathrm{kg}$ b.wt) groups by $\mathrm{S} / \mathrm{C}$ injection in Holstein calves.

$\begin{array}{lllll}\text { Parameter } & \text { Group } & \text { Zero week } & \text { First week } & \begin{array}{l}\text { Second } \\ \text { week }\end{array} \\ & & & & \\ \text { Tp (g/dl) } & \text { control } & 6.18 \pm 0.51^{\mathrm{a}} & 7.05 \pm 0.36^{\mathrm{a}} & 5.58 \pm 0.54^{\mathrm{a}} \\ & \text { Treated } & 7.99 \pm 0.41^{\mathrm{a}} & 8.59 \pm 0.30^{\mathrm{a}} & 7.78 \pm 0.52^{\mathrm{a}} \\ \text { Alb (g/dl) } & \text { control } & 1.53 \pm 0.28^{\mathrm{a}} & 2.05 \pm 0.54^{\mathrm{a}} & 0.91 \pm 0.15^{\mathrm{a}} \\ & \text { Treated } & 1.77 \pm 0.29^{\mathrm{a}} & 2.23 \pm 0.49^{\mathrm{a}} & 1.08 \pm 0.07^{\mathrm{a}} \\ \text { AST (U/L) } & \text { control } & 34.50 \pm 3.27^{\mathrm{a}} & 25.33 \pm 0.98^{\mathrm{b}} & 30.16 \pm 2.54^{\mathrm{a}} \\ & \text { Treated } & 29.32 \pm 2.32^{\mathrm{a}} & 30.83 \pm 0.71^{\mathrm{a}} & 31.50 \pm 3.78^{\mathrm{a}} \\ \text { ALT (U/L) } & \text { control } & 10.33 \pm 0.89^{\mathrm{a}} & 7.93 \pm 0.44^{\mathrm{a}} & 8.00 \pm 0.84^{\mathrm{a}} \\ & \text { Treated } & 9.33 \pm 0.29^{\mathrm{a}} & 7.50 \pm 0.26^{\mathrm{a}} & 5.16 \pm 0.12^{\mathrm{b}} \\ \text { ALP (U/L) } & \text { control } & 9.56 \pm 0.13^{\mathrm{b}} & 9.57 \pm 0.60^{\mathrm{b}} & 12.63 \pm 1.38^{\mathrm{a}} \\ & \text { Treated } & 13.18 \pm 0.95^{\mathrm{a}} & 12.21 \pm 0.82^{\mathrm{a}} & 10.53 \pm 1.97^{\mathrm{a}} \\ \text { Urea } & \text { control } & 41.91 \pm 2.05^{\mathrm{a}} & 29.39 \pm 2.18^{\mathrm{a}} & 35.45 \pm 2.72^{\mathrm{a}} \\ \text { (mg/dl) } & \text { Treated } & 30.33 \pm 2.29^{\mathrm{a}} & 32.00 \pm 2.88^{\mathrm{a}} & 38.51 \pm 2.80^{\mathrm{a}} \\ & & & & \\ \text { Creatinine } & \text { control } & 1.23 \pm 0.20^{\mathrm{a}} & 0.65 \pm 0.03^{\mathrm{b}} & 1.07 \pm 0.12^{\mathrm{a}} \\ \text { (mg/dl) } & \text { Treated } & 1.55 \pm 0.14^{\mathrm{b}} & 1.39 \pm 0.17^{\mathrm{a}} & 1.31 \pm 0.23^{\mathrm{a}} \\ \text { Globulin } & \text { control } & 4.65 \pm 0.34^{\mathrm{b}} & 5.00 \pm 0.52^{\mathrm{b}} & 4.67 \pm 0.51^{\mathrm{b}} \\ \text { (g/dl) } & \text { Treated } & 6.22 \pm 0.41^{\mathrm{a}} & 6.36 \pm 0.32^{\mathrm{a}} & 6.7 \pm 0.18^{\mathrm{a}}\end{array}$

\section{DISCUSSION}

The signs of bovine respiratory disease were found among the infected animals that were found through the decrease in ruminal movement and increase in rectal temperature. Various degrees of ocular and nasal charges were also detected that was accompanied by a significant increase in respiratory movement and high coughing rates in diseased individuals. The infected pathogen detected in nasal swabs was mainly P.multocida (30\%) as well as M. haemolytica $(70 \%)$, which was found by a study conducted by Conlon et al., [30], where M. haemolytica showed the predominant isolate in stressed feeder calves.

The comparison between tilmicosin $10 \mathrm{mg} / \mathrm{kg} . \mathrm{bwt} . \mathrm{s} / \mathrm{c}$ injected calves group and control group show a significant decrease in RBCs count in zero weeks and the second week for the infected group, and that is confirmed by the hematocrit blood test (HCT) and red blood cells distribution width (RDW$\mathrm{CV}$ ) which show the same result to the infected group, also, to mean corpuscular volume (MCV) which show a significant decrease in zero weeks and the first week for the infected group. And these results agree with Oztekin et al., [31] and Altunok et al., [32] who reported that tilmicosin caused significant changes in erythrocytic parameters in mice and rabbits. (Table 5).

Although there is no significant change in hemoglobin (Hgb) for the two groups, there is a significant increase in mean corpuscular hemoglobin in zero weeks, and mean corpuscular hemoglobin concentration in zero weeks and the second week for the tilmicosin treated group compared by the control group (Table 5) and these results are agreed with Scorneaux et.al. [33] and Altunok, et.al. [32] which did not record any change in $\mathrm{Hgb}$ after tilmicosin injection in the rabbit.

The significant decrease in platelet count (PLT) in the second week for the tilmicosin treated group with no significant change in mean platelet volume (MPV) and a significant decrease in platelet distribution width (PDW-CV) in zero week and the first week for tilmicosin treated group (Table 5). There is a significant increase in Procalcitonin (PCT) in zero weeks for the treated group with a significant decrease in the second week (Table 5).

The significant increase in WBCs in the second week for the tilmicosin treated group does not agree with Khan and Zafar, [34] which record there is a temporary decrease in WBCs with tilmicosin treatment, but the significant decrease in a lymphocyte in zero weeks and the second week for the tilmicosin treated group, a significant increase in neutrophil count in zero week and the second week for the same group with no significant change in monocyte and eosinophil. (Table $5)$, and agreed with the oxidative stress effect of tilmicosin in mice [32] and [35] and rats [36] and chicks [37].

The changes in biochemical parameters for the tilmicosin $10 \mathrm{mg} / \mathrm{kg}$. bwt.s $/ \mathrm{c}$ injected calves show a significant increase in globulin level result from inflammatory effect with on significant change in total protein and albumin level. However, the significant increase in alkaline phosphatase level in the zero weeks and the first week for the same group indicate injury in the liver, gall bladder, and bone marrow but there is a significant decrease of ALT liver enzyme in the second week with a significant increase of AST liver enzyme in the first week only. The renal function is reflected by urea level which shows no significant change with a significant decrease level in zero weeks and a significant increase in the first week.

In conclusion, tilmicosin induced a significant decrease in RBCs \& lymphocyte and a significant increase in WBCs, neutrophil, platelets, and globulin.

\section{REFERENCES}

[1] Abutarbush SM, Schunicht OC, Wildman BK, Hannon SJ, Jim GK, Ward TI, et al. Comparison of enrofloxacin and ceftiofur sodium for the treatment of relapse of undifferentiated fever/bovine respiratory disease in feedlot cattle. Can Vet J. 2012;53:57.

[2] Ramadan M, Ghanem M, El Attar HE, Abdel-Raoof Y. Evaluation of Clinical and Hematobiochemical alterations in naturally occurring bovine 
respiratory disease in feedlot cattle calves in Egypt. Ben Vet Med J. 2019;36:305-13. https://doi.org/10.21608/bvmj.2019.16753.1088

[3] Torres S, Thomson DU, Bello NM, Nosky BJ, Reinhardt CD. Field study of the comparative efficacy of gamithromycin and tulathromycin for the control of undifferentiated bovine respiratory disease complex in beef feedlot calves at high risk of developing respiratory tract disease. Amer J Vet Res. 2013;74:839-46. https://doi.org/10.2460/ajvr.74.6.839

[4] Regev-Shoshani G, Vimalanathan S, Prema D, Church J, Reudink M, Nation $\mathrm{N}$, et al. Safety, bioavailability and mechanism of action of nitric oxide to control Bovine Respiratory Disease Complex in calves entering a feedlot. Res Vet Sci. 2014;96:328-37. https://doi.org/10.1016/j.rvsc.2013.12.012

[5] Kirchhoff J, Uhlenbruck S, Goris K, Keil GM, Herrler G. Three viruses of the bovine respiratory disease complex apply different strategies to initiate infection. Vet Res. 2014;45:1-12. https://doi.org/10.1186/1297-9716-4520

[6] Ozkanlar Y, Aktas M, Kaynar O, Ozkanlar S, Kireccl E. Bovine respiratory disease in naturally infected calves: Clinical signs, blood gases and cytokine response. Rev de Méd Vét. 2012;163:123-30.

[7] Zeineldin M, Ghanem M, El-Raof YA, Elattar H. Clinical Utilization of Pointof-Care Blood L-Lactate Concentrations in Naturally Occurring Respiratory Disease in Feedlot Cattle.Pak Vet J. 2017;37

[8] Kabeta $T$, Fikadu $T$, Zenebe $T$, Kebede $G$. Review on the pneumonic pasteurellosis of cattle. Acad J Ani Dis. 2015;4:177-84.

[9] Williams J. Antibiotic and Chemotherapy. Anti-infective Agents and their use in Therapy, Roger G. Finch, David Greenwood, S. Ragnar Norrby \& Richard J. Whitley (editors). Edinburgh, London, New York, Philadelphia, St Louis, Sydney, Toronto: Churchill Livingstone, 2003. xii+ 964 pp. Pricef 115.00. ISBN 0443071292. Royal Society of Tropical Medicine and Hygiene; 2003.

[10] Ribeiro CMP, Hurd H, Wu Y, Martino ME, Jones L, Brighton B, et al. Azithromycin treatment alters gene expression in inflammatory, lipid metabolism, and cell cycle pathways in well-differentiated human airway epithelia. PloS one. 2009;4:e5806. https://doi.org/10.1371/journal.pone.0005806

[11] Morck D, Merrill JK, Thorlakson BE, Olson M, Tonkinson L, Costerton J. Prophylactic efficacy of tilmicosin for bovine respiratory tract disease. J Amer Vet Med Ass. 1993;202:273-7.

[12] Gorham PE, Carroll LH, McAskill JW, Watkins LE, Ose EE, Tonkinson LV, et al. Tilmicosin as a single injection treatment for respiratory disease of feedlot cattle. Can Vet J. 1990;31:826.

[13] Thomson R. A perspective on respiratory disease in feedlot cattle. Can Vet J. 1980;21:181.

[14] Morck D, Merrill J, Gard M, Olson M, Nation P. Treatment of experimentally induced pneumonic pasteurellosis of young calves with tilmicosin. Can J Vet Res. 1997;61:187.

[15] McGuirk SM. Disease management of dairy calves and heifers. Vet Clin N Amer. 2008;24:139-53. https://doi.org/10.1016/j.cvfa.2007.10.003

[16] Radostits OM, Mayhew IG, Houston DM. Veterinary clinical examination and diagnosis: WB Saunders; 2000.

[17] Ziv G, Shbm-Tov M, Glickman A, Winkler M, Saran A. Tilmicosin antibacterial activity and pharmacokinetics in cows. J Vet Pharmacol Therap. 1995;18:340-5. https://doi.org/10.1111/j.13652885.1995.tb00601.x

[18] Jain NC. Schalm's veterinary hematology: Lea \& Febiger; 1986.

[19] Pagana KD, Pagana TJ. Mosby's Manual of Diagnostic and Laboratory TestsE-Book: Elsevier Health Sciences; 2017.

[20] Fischbach FT, Dunning MB. A manual of laboratory and diagnostic tests: Lippincott Williams \& Wilkins; 2009.

[21] Chernecky C, Berger B. Doppler Ultrasonographic Flow Studies (Includes Carotid Doppler, Carotid Artery Echography, Carotid Artery Ultrasonography, Duplex Ultrasonography, Transcranial Doppler Ultrasonography)-Diagnostic. Laboratory Tests and Diagnostic Procedures 5th ed St Louis, MO: Saunders Elsevier. 2008.
[22] Thefeld W. Annuals of Clinical Biochemistry. Cited by Wooton and Freemon. 1974:79.

[23] Ghanem M, Anwar M, Abd El-Raof Y, El-Attar H. Clinical, hematological and biochemical changes in lambs suffered from nutritional muscular dystrophy. Ben Vet Med J. 2016;30:61-6. https://doi.org/10.21608/bvmj.2016.31331

[24] Walker HK, Hall WD, Hurst JW. Peripheral Blood Smear--Clinical Methods: The History, Physical, and Laboratory Examinations: Butterworths; 1990.

[25] Peake $M$, Whiting $M$. Measurement of serum creatinine-current status and future goals. Clin Biochem Rev. 2006;27:173.

[26] Rimler R, Rhoades K. Hyaluronidase and chondroitinase activity of Pasteurella multocida serotype B: 2 involved in hemorrhagic septicaemia. Vet Rec. 1994;134:67-8. https://doi.org/10.1136/vr.134.3.67

[27] Jamaludin R, Blackall P, Hansen M, Humphrey S, Styles M. Phenotypic and genotypic characterisation of Pasteurella multocida isolated from pigs at slaughter in New Zealand. New Vet J. 2005;53:203-7. https://doi.org/10.1080/00480169.2005.36505

[28] Heddleston K, Gallagher J, Rebers P. Fowl cholera: gel diffusion precipitin test for serotyping Pasteurella multocida from avian species. Avi dis. 1972:925-36. https://doi.org/10.2307/1588773

[29] Graham JW. Multiple imputation and analysis with SPSS 17-20. Missing Data: Springer; 2012. p. 111-31. https://doi.org/10.1007/978-1-46144018-5_5

[30] Conlon JA, Shewen P, Lo R. Efficacy of recombinant leukotoxin in protection against pneumonic challenge with live Pasteurella haemolytica A1. Infection and immunity. 1991;59:587-91. https://doi.org/10.1128/IAI.59.2.587-591.1991

[31] Oztekin E, Sivrikaya A, Col R, Elmas M, Bas A. Effects of different doses of tilmicosin on malondialdehyde and glutathione concentrations in mice. Acta Veterinaria Brno. 2004;73:69-72. https://doi.org/10.2754/avb200473010069

[32] Altunok V, Yazar E, Elmas M, Traş B, Baş A, Cöl R. Investigation of haematological and biochemical side effects of tilmicosin in healthy New Zealand rabbits. J Vet Med, Series B. 2002;49:68-70. https://doi.org/10.1046/j.1439-0450.2002.00502.x

[33] Scorneaux B, Shryock TR. Intracellular accumulation, subcellular distribution, and efflux of tilmicosin in bovine mammary, blood, and lung cells. J Dai Sci. 1999;82:1202-12. https://doi.org/10.3168/jds.S00220302(99)75343-9

[34] Khan R, Kazmi I, Afzal M, Al Abbasi FA, Mushtaq G, Ahmad A, et al. Fixed dose combination therapy loperamide and niacin ameliorates diethylnitrosamine-induced liver carcinogenesis in albino Wistar rats. RSC Advances. 2015;5:67996-8002. https://doi.org/10.1039/C5RA11201J

[35] Yapar K, Kart A, Karapchlivan M. Effects of different doses of tilmicosin on some biochemical parameters and antioxidant status in serum and cardiac tissues in mice. Bull Vet Ins Pula. 2006;50:605.

[36] Cetin N, Boyraz U, Cetin E. Ghrelin alleviates tilmicosin-induced myocardial oxidative stress in rats. J Ani Vet Adv. 2011;10:2038-42. https://doi.org/10.3923/javaa.2011.2038.2042

[37] Eraslan G. Effects of different doses of tilmicosin on erythrocyte catalase activity and plasma malondialdehyde levels in chicks. Bull Vet Ins Pula. 2007:51:145.

[38] Xie S, Wang, F., Wang, Y., Zhu, L., Dong, Z., Wang, X. \& Zhou, W. . Acute toxicity study of tilmicosin-loaded hydrogenated castor oil-solid lipid nanoparticles. Particle and fibre toxicology. 2011;8:33. https://doi.org/10.1186/1743-8977-8-33 